\title{
Blood Concentrations of Thyroid Hormones and Lipids and Content of Lipids in the Liver in Dairy Cows in Transitional Period
}

\author{
R. DJOKOVIĆ ${ }^{1}$, H. ŠAMANC ${ }^{2}$, M. JOVANOVIĆ ${ }^{3}$, Z. NIKOLIĆ ${ }^{2}$ \\ ${ }^{1}$ Department of Animal Science, Faculty of Agronomy, Čačak, University of Kragujevac, ${ }^{2}$ Department for \\ Diseases of Ruminants and Pigs, ${ }^{3}$ Department of Pathology, Faculty of Veterinary Medicine, University of \\ Belgrade, Serbia and Montenegro
}

Received March 16, 2006

Accepted November 15, 2007

\begin{abstract}
Djoković R., H. Šamanc, M. Jovanović, Z. Nikolić: Blood Concentrations of Thyroid Hormones and Lipids and Content of Lipids in the Liver in Dairy Cows in Transitional Period. Acta Vet. Brno 2007, 76: 525-532.

The aim of the present investigation was to determine the correlation in the blood concentrations of thyroid hormones, lipids and glucose as well as the content of lipids in the liver of dairy cows in the transitional period.

The animals $(n=40)$ were divided into four groups: the first group included late pregnant cows $(n=10)$ from the $10^{\text {th }}$ to $4^{\text {th }}$ day before calving; the second group included late pregnant cows $(n=$ $10)$ from the $4^{\text {th }}$ to $1^{\text {st }}$ day before calving; the third group included clinically puerperal healthy cows $(\mathrm{n}=10)$, whereas the fourth group included puerperal cows with clinical symptoms of ketosis $(\mathrm{n}=$ 10). Samples of liver and blood tissues were taken from all cows. Pathohistological examination of liver samples showed statistically significantly higher $(p<0.01)$ lipid infiltration in ketotic cows compared to healthy cows in late pregnancy and puerperium. Biochemical examination of blood serum showed significantly higher values $(p<0.01)$ of free fatty acids in ketotic cows, such as significantly lower blood concentrations of glucose $(p<0.01)$, triacylglycerols $(p<0.01)$, total cholesterol $(p<0.05)$, triiodthyronine $(p<0.05)$ and thyroxine $(p<0.05)$, compared to the values obtained in the blood serum in the groups of healthy cows before and after calving. In this study, significantly positive correlations were determined between the content of lipids in the liver and blood concentration of free fatty acids $(\mathrm{r}=0.51 ; p<0.05)$ as well as the negative ones between the content of lipids in the liver and blood concentrations of glucose $(\mathrm{r}=-0.69 ; p<0.05)$, triacylglycerols $(\mathrm{r}=-0.55 ; p<0.05)$ and total cholesterol $(\mathrm{r}=-0.50 ; p<0.05)$ in the group of ketotic cows. Our investigations suggested that a hypothyroidal status was established in ketotic cows and that the blood concentrations of free fatty acids, triacylglycerols, total cholesterol and glucose served as major biochemical indicators in determining liver steatosis in the dairy cows in the transitional period.
\end{abstract}

Liver steatosis, ketosis, free fatty acids, triacylglycerol, triiodthyronine, thyroxine

The transitional period in dairy cows included 3 weeks before and 3 weeks after calving, when metabolic processes were adapted to providing energy and nutrients required for the synthesis of milk compounds (Grummer 1995; Overton and Waldron 2004).

Early lactation in dairy cows resulted in negative energy balance, high mobilisation of lipids from bodily fat reserves as well as hypoglycaemia (Veenhuizen et al.1991; Vázquez-Añón et al.1994; Reist et al. 2002).

Lipid mobilisation characterised by highly concentrated free fatty acids in blood starts in a high degree of pregnancy, reaching its maximum in early lactation. Free fatty acids are reesterified and accumulated in the form of triacylglycerols in the liver, primarily due to the decreasing capacity of hepatocytes for transport of lipids by very low density lipoproteins (VLDL). As a result, lipid mobilisation intense ketogenosis and lipogenesis in the liver and consequently lower concentrations of glucose, triacylglycerol and total cholesterol in blood were manifested (Herdt et al. 1983; Holtenius 1989; Veenhuizen et al. 1991; Grummer 1993; Vázquez-Añón et al. 1994; Sevinc et al. 2003). Primary homeorhetic

Address for correspondence:

Dr Radojica Djoković

Department of Animals Science, Faculty of Agriculture Čačak

University of Kragujevac

Cara Dušana 34, 32000 Čačak, Serbia and Montenegro
Phone: +381 32/303 400,313410

Fax: +381 32/303 401

E-mail: djokovici@ptt.yu

http://www.vfu.cz/acta-vet/actavet.htm 
adaptation of glucose metabolism in early lactation leads to increased gluconeogenesis in the liver to direct glucose into the mammary gland for lactose synthesis (Reynolds et al. 2003). If the degree of gluconeogenesis does not meet the increased needs of glucose in dairy cows in early lactation, hypoglycaemia, ketonaemia and ketonuria are likely to occur (Young 1977).

The hormonal activity of the thyroid gland has an important role in the transitional period for determining cell metabolism intensity, metabolism of lipids and carbohydrates and the lactation course itself by its thyroid hormones (Nikolić et al. 1997). A positive correlation was established between thyroid hormones in blood and energy balance (Reist et al. 2002) and a negative one between concentrations of triiodthyronine and thyroxine in blood and milk production (Nixon et al. 1988). Under the conditions of negative energy balance and high lipid mobilisation, the concentrations of thyroid hormones were reduced in the blood of dairy cows in the transitional period, with a markedly declined triiodthyronine in blood shortly before and after calving (Blum et al. 1983; Gerloff et al. 1986; Nikolić et al. 1997; Reist et al. 2002; Pezzy et al. 2003).

Kapp et al. (1979) noticed that diffuse lipid infiltration of hepatocytes, impairing most of them, occurred due to reduced mitochondria capacity to oxidize fatty acids at decreased levels of thyroid hormones in blood.

The aim of the present study was to determine a correlation between blood concentration of thyroid hormones, lipids and glucose as well as the content of lipids in the liver of dairy cows in the transitional period.

\section{Materials and Methods}

Late pregnant and calved cows $(n=40)$ were chosen from a Holstein dairy herd $(1,100$ dairy cows $)$ and divided into four groups: the first group $(A)$ included late pregnant cows $(n=10)$ from the $10^{\text {th }}$ to $4^{\text {th }}$ day before calving; the second group $(B)$ included late pregnant cows $(n=10)$ from the $4^{\text {th }}$ to $1^{\text {st }}$ day before calving; the third group (C) included clinically healthy puerperal cows $(n=10)$, whereas the fourth group (D) included cows with clinical symptoms of ketosis $(n=10)$. The liver and blood samples were taken from all the cows. The late pregnant cows were selected during a certain period on the basis of the time of artificial insemination and after detection of conception. Calved cows were selected as single selection in calving stalls. The diagnosis of ketosis was based on the clinical symptoms (reduced appetite, rumen atony, behavioural changes) and determined high concentrations of urinary ketone. The presence of ketone bodies in urine was examined using the Lestradet test (Rosenberger et al. 1979; Kégl and Gaal 1992). Healthy cows before and after calving did not show clinical symptoms of ketosis and urinary ketone bodies were not determined in those cows.

The cows were on average $4-6$ years old, weighing $661.3 \pm 24.3 \mathrm{~kg}$ in groups of cows in late pregnancy and $576.1 \pm 23.35 \mathrm{~kg}$ in groups of cows in early lactation. There were 3 lactations with a mean milk yield of 7625.2 \pm 329.171 (calculated over 305 days) in the previous lactation. The experimental cows were kept in tie-up stalls in barn housing. The meal was prepared in a manner to suit the energy needs of animals in late pregnancy and early lactation. The cows in late pregnancy were fed a diet consisting of $3 \mathrm{~kg}$ lucerne hay, $3 \mathrm{~kg}$ wheat straw, $10 \mathrm{~kg}$ maize silage (30\% DM), $4 \mathrm{~kg}$ lucerne haylage, $2 \mathrm{~kg}$ maize ear silage (68\% DM), $0.5 \mathrm{~kg}$ dry sugarbeet pulp, $1.5 \mathrm{~kg}$ concentrate $(30 \% \mathrm{CP})$. The dietary nutrient content for dairy cows in late pregnancy is given in Table 1 .

The cows in early lactation were fed a diet consisting of $4 \mathrm{~kg}$ lucerne hay, $15 \mathrm{~kg}$ maize silage $(30 \% \mathrm{DM}), 8 \mathrm{~kg}$ lucerne haylage, $4 \mathrm{~kg}$ maize ear silage $(68 \% \mathrm{DM}), 2 \mathrm{~kg}$ dry sugarbeet pulp, $2 \mathrm{~kg}$ extruded soybean grains, $4.5 \mathrm{~kg}$

Table 1 . Nutrient contents in daily ration for dairy cows in high pregnancy

\begin{tabular}{|l|c|}
\hline Dry matter (DM), kg & 12.1 \\
\hline Net energy of lactation (NEL), MJ & 66.2 \\
\hline Crude protein (CP), \% DM & 12.1 \\
\hline Rumen undegradable protein (RUP), \% CP & 35.82 \\
\hline Fat, \% DM & 3.09 \\
\hline Fibre, \% DM & 25.12 \\
\hline Acid detergent fibre (ADF), \% DM & 32.33 \\
\hline Neutral detergent fibre (NDF), \% DM & 49.08 \\
\hline Iodine (I), mg/kg (DM) & 0.6 \\
\hline
\end{tabular}
for dairy cows in early lactation is given in Table 2

Blood samples for serum were collected from the jugular vein ( 2 test tubes of blood taken per punction, approximately $20 \mathrm{ml}$ blood) from 10:00 h to noon or from 4 to $6 \mathrm{~h}$ after milking and feeding. The blood samples were allowed to clot spontaneously (approximately $15 \mathrm{~min}$ ) at room temperature. The serum was then decanted at $1,000 \mathrm{~g}$ and preserved at $-18^{\circ} \mathrm{C}$ until analysed.

Shortly after blood sampling the liver was sampled through liver percutaneous biopsy using a biopsy instrument (Gaal 1995), following the modified method of Gaal after Hojovcova and Kacafirek 
Table 2. Nutrient contents in daily ration for dairy cows in the early lactation

\begin{tabular}{|l|c|}
\hline Dry matter (DM), kg & 21.5 \\
\hline Net energy of lactation (NEL), MJ & 153.2 \\
\hline Crude protein (CP), \% DM & 18.3 \\
\hline Rumen undegradable protein (RUP), \% CP & 39.69 \\
\hline Fat, \% DM & 4.92 \\
\hline Fibre, \% DM & 17.2 \\
\hline Acid detergent fibre (ADF), \% DM & 22.6 \\
\hline Neutral detergent fibre (NDF), \% DM & 37.16 \\
\hline Iodine (I), mg/kg (DM) & 0.6 \\
\hline
\end{tabular}

in the blood serum CHOD-PAP method (041015), reagent Serbolab (Serbia) by means of microtitre reader MULTISKAN MCC/340 (Helsinki, Finland). All biochemical variables were assayed at the laboratory of Institute for the Application of Nuclear Energy (INEP) Zemun.

Liver tissue was pathohistologically tested for the lipid content at the Pathological Department of the Faculty of Veterinary Medicine in Belgrade. The liver specimens were fixed in neutral $10 \%$ formaldehyde solution. For pathohistological determining of lipids, sections were made using a freezing microtome stained with Sudan III method. Lipid contained in the hepatocytes was determined through computer image analysis (Software Q Win) made on the appliance (Leica Q $500 \mathrm{MC}$ ) at the Technical Faculty in Čačak.

The significance of differences of thyroid hormones, lipids and glucose concentrations in the blood serum and the content of lipids in the liver between the animal groups used in experiment were determined by ANOVA procedure. Data were expressed as means \pm standard deviation $(x \pm S D)$. Correlation coefficients were obtained using linear regression models. Differences with $p<0.05$ and $p<0.01$ were considered statistically significant (Microsoft STATISTICA ver. 5.0, Stat. Soft. Inc. 1995).

\section{Results and Discussion}

The results of pathohistological assay made on the liver specimens denoted that lipid infiltration of hepatocyte was not determined in the pregnant cows, nor was it determined in the puerperal ones ( $<10 \%$ of lipids). In ketotic cows various degrees of fatty liver were estimated. Results of the content of lipids in the liver in cows in the transitional period are shown in Fig. 1.

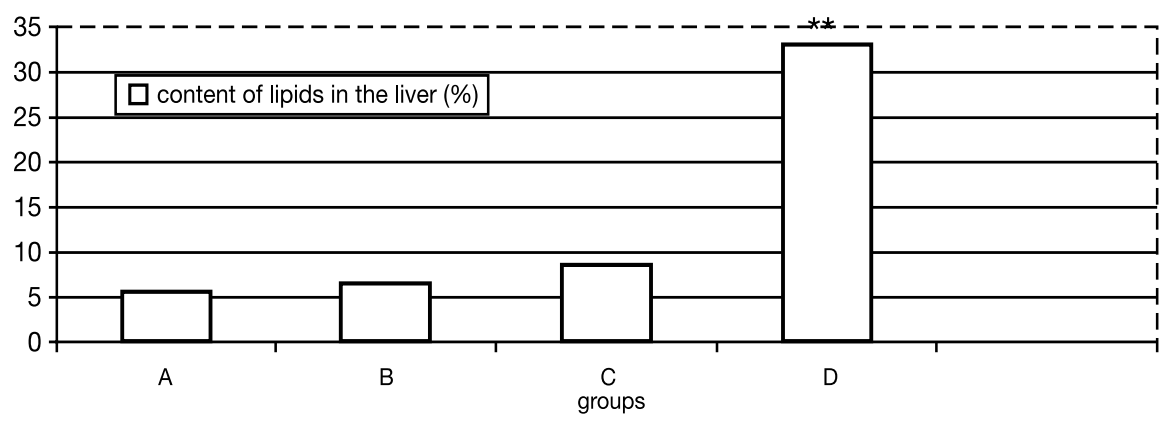

Fig. 1. The content of lipids in the liver (\%) in the groups of the cows in transitional period (A - group of cows from $10^{\text {th }}$ to $4^{\text {th }}$ days before calving; B - group of cows from $4^{\text {th }}$ to $1^{\text {st }}$ days befor calving; C - group of puerperal healthy cows; D - group of puerperal ketotic cows). ${ }^{* *} p<0.01$ (between groups A, B, C and D)

The content of lipids in the liver of healthy cows before and after calving was in the physiological range (around $5 \%$ ) and was $5.30 \pm 1.10 \%$ (group of cows from the $10^{\text {th }}$ to $4^{\text {th }}$ day before calving), $6.31 \pm 1.18 \%$ (group of cows since the $4^{\text {th }}$ to $1^{\text {st }}$ day before calving) and $8.37 \pm 1.24 \%$ (puerperal healthy cows). In the group of ketotic cows the content of lipids in the liver was $32.91 \pm 13.23 \%$ and it was higher $(p<0.01)$ compared to groups healthy cows before and after calving. 
Results of single values of the content of the lipids in the liver of ketotic cows are shown in Table 3.

Table 3. The content of the lipids (\%) in the liver of ketotic cows

\begin{tabular}{|l|c|c|c|c|c|c|c|c|c|c|c|}
\hline $\begin{array}{l}\text { Ordinal } \\
\text { number }\end{array}$ & 1 & 2 & 3 & 4 & 5 & 6 & 7 & 8 & 9 & 10 & $\bar{x}$ \\
\hline $\begin{array}{l}\text { Percentage } \\
\text { of lipids }\end{array}$ & 25.44 & 23.66 & 23.98 & 61.15 & 44.82 & 42.56 & 16.04 & 31.86 & 32.98 & 26.62 & 32.91 \\
\hline
\end{tabular}

Results of biochemical estimation in the blood serum of groups of cows in transitional period are shown in Table 4.

Table 4. Selected metabolic profile variables (means \pm standard deviation) in the groups of the cows in the transitional period (A - group of cows from $10^{\text {th }}$ to $4^{\text {th }}$ days before calving, B - group of cows from $4^{\text {th }}$ to $1^{\text {st }}$ days before calving, C - group of puerperal healthy cows, D - group of puerperal ketotic cows)

\begin{tabular}{|l|c|c|c|c|}
\hline \multirow{2}{*}{ Group } & \multicolumn{2}{|c|}{ Late pregnancy } & \multicolumn{2}{c|}{ Puerperium } \\
\cline { 2 - 5 } & A & B & C & D \\
\hline $\mathrm{n}$ & 10 & 10 & 10 & 10 \\
\hline Glucose $\left(\mathrm{mmol} \cdot 1^{-1} /\right)$ & $2.94 \pm 0.32^{\mathrm{A}}$ & $3.12 \pm 0.42^{\mathrm{B}}$ & $2.71 \pm 0.35^{\mathrm{bc}}$ & $1.80 \pm 0.43^{\mathrm{ABCD}}$ \\
\hline FFA $\left(\mathrm{mmol} \cdot \mathrm{l}^{-1}\right)$ & $0.27 \pm 0.14^{\mathrm{A}}$ & $0.54 \pm 0.26^{\mathrm{ABc}}$ & $0.46 \pm 0.10^{\mathrm{AC}}$ & $0.74 \pm 0.12^{\mathrm{ACD}}$ \\
\hline TAG $\left(\mathrm{mmol} \cdot \cdot^{-1}\right)$ & $0.32 \pm 0.04^{\mathrm{A}}$ & $0.41 \pm 0.03^{\mathrm{ABC}}$ & $0.35 \pm 0.04^{\mathrm{C}}$ & $0.27 \pm 0.03^{\mathrm{ABCD}}$ \\
\hline Total cholesterol $\left(\mathrm{mmol} \cdot l^{-1}\right)$ & $1.75 \pm 0.20^{\mathrm{a}}$ & $1.71 \pm 0.30^{\mathrm{b}}$ & $1.86 \pm 0.62^{\mathrm{c}}$ & $1.39 \pm 0.29^{\mathrm{acd}}$ \\
\hline $\mathrm{T}_{3}\left(\mathrm{nmol} \cdot \cdot^{-1}\right)$ & $2.58 \pm 0.53^{\mathrm{a}}$ & $2.31 \pm 0.41^{\mathrm{b}}$ & $2.22 \pm 0.74^{\mathrm{c}}$ & $1.58 \pm 0.70^{\mathrm{abcd}}$ \\
\hline $\mathrm{T}_{4}\left(\mathrm{nmol} \cdot \cdot^{-1}\right)$ & $50.68 \pm 9.34^{\mathrm{a}}$ & $45.21 \pm 4.28^{\mathrm{b}}$ & $45.75 \pm 14.27^{\mathrm{c}}$ & $35.06 \pm 12.43^{\mathrm{abcd}}$ \\
\hline
\end{tabular}

Values marked by letters $\left({ }^{a}, b, c, d\right)$ in one row describe significant differences; values marked by small letter differ significantly $(p<0.05)$; values marked by capital letter differ high-significantly $(p<0.01)$.

Correlation coefficients between biochemical variables in blood and the content of lipids in the liver of ketotic cows are shown in Table 5.

Table 5. Correlation coefficients between biochemical indicators in blood and the content of lipids in the liver of ketotic cows

\begin{tabular}{|l|c|c|c|c|c|c|c|}
\hline & Glucose & $\mathrm{T}_{3}$ & $\mathrm{~T}_{4}$ & FFA & TAG & $\begin{array}{c}\text { Total } \\
\text { Cholesterol }\end{array}$ & $\begin{array}{c}\text { \% lipids in } \\
\text { liver }\end{array}$ \\
\hline Glucose & - & -0.01 & -0.17 & -0.38 & $0.54^{*}$ & 0.17 & $-0.69^{*}$ \\
\hline $\mathrm{T}_{3}$ & - & - & $0.73^{*}$ & $-0.50^{*}$ & -0.19 & -0.03 & -0.19 \\
\hline $\mathrm{T}_{4}$ & - & - & - & -0.10 & -0.19 & -0.06 & -0.04 \\
\hline FFA & - & - & - & - & $-0.64 *$ & -0.34 & $0.51^{*}$ \\
\hline TAG & - & - & - & - & - & 0.42 & $-0.55^{*}$ \\
\hline Total cholesterol & - & - & - & - & - & - & $-0.50^{*}$ \\
\hline$\%$ lipids in liver & - & - & - & - & - & - & - \\
\hline
\end{tabular}

$* p<0.05$

From Table 4 it can be seen that significant changes of most indicators in blood occurred in the group of ketotic cows, i.e. the group of cows with fatty liver.

One of the tested indicators in blood in this research was the glucose concentration in blood. In the group of puerperal healthy cows the glucose concentration in blood is significantly lower $(p<0.05)$ compared to the groups of late pregnant cows, whereas hypoglycaemia was determined in ketotic cows. It was significant lower $(p<0.01)$ compared to the groups of healthy cows before and after calving. Similar results were obtained by other authors (Veenhuizen et al. 1991; Vazquez-Anon et al. 1994). In our testing we found a negative correlation $(\mathrm{r}=-0.69 ; p<0.05)$ between the glucose concentrations in blood and 
the content of lipids in the liver of ketotic cows. Also a significantly positive correlation $(\mathrm{r}=0.54 ; p<0.05)$ among glucose and TAG levels in blood should be compared to previous results (Veenhuizen et al. 1991; Vázquez-Añón et al. 1994; Codorniga-Valino et al. 1997) showing that during intensive lipid mobilisation and accumulated TAG in the liver cells, their gluconeogenetic ability is reduced and consequently hypoglycaemia is manifested in animals.

Energy metabolism of dairy cows in the transitional period is closely linked to lipid metabolism. The best indicator of negative energy balance and the degree of mobilization of lipids from bodily fat reserves in the transitional period is the increase of FFA concentrations in blood (Veenhuizen et al. 1991; Vázquez-Añón et al. 1994; Reist et al. 2002; Overton and Waldron 2004). There is an increase in blood FFA concentrations, which are bound to albumin and transported to the liver. In the liver, they may be oxidized to $\mathrm{CO}_{2}$ or ketone bodies or they are re-esterified to TAG. TAG are then combined with phospholipids, cholesterol and apoproteins, with the production of lipoproteins and mainly lipoproteins of very low density (VLDH) that carry TAG to various tissues (Holtenius 1989).

Significantly higher FFA concentrations were determined in the blood $(p<0.01)$ of ketotic cows compared to the groups of healthy cows before and after calving. Significantly positive correlation $(\mathrm{r}=0.51 ; p<0.05)$ among the FFA in blood and the content of lipids in the liver was determined in this experiment, as well as negative correlation $(r=-0.64$; $p<0.05$ ) among the FFA and TAG concentrations in blood of ketotic cows. These results were in accordance with the results of other authors (Veenhuizen et al. 1991; Reist et al. 2002), clearly showing that a significant increase of FFA concentrations in blood causes an increase of the content of lipids in liver cells and a decrease of TAG concentrations in blood.

In late pregnant cows the FFA concentrations in blood are higher than the physiological range for cattle $\left(0.1-0.35 \mathrm{mmol} \cdot \mathrm{l}^{-1}\right.$, Jovanović 1984). However, the FFA concentrations were significantly increasing $(p<0.01)$ (among the group of cows from the $10^{\text {th }}$ to $4^{\text {th }}$ day before calving and the group of cows from the $4^{\text {th }}$ to $1^{\text {st }}$ day before calving). As the calving day was approaching lipid mobilisation began, from four days to one day before calving. Similar results were obtained by Veenhuizen et al. (1991) and Dyk et al. (1995).

In cows with fatty liver the TAG and total cholesterol concentrations in the blood declined (Sevinc et al. 2003). TAG concentrations in the blood of ketotic cows were determined to be significantly lower $(p<0.01)$ than the values in groups of healthy cows before and after calving. Significant negative correlation $(\mathrm{r}=-0.55 ; p<0.05)$ between the TAG concentrations in blood and content of lipids in the liver of ketotic cows were determined as well. The results unambiguously indicated that the blood TAG concentrations decreased and proportionally their amount increased in the liver cells in which they accumulated. These results are in accordance with observations by Holtenius (1989) and Sevinc et al. (2003).

In this study the total cholesterol concentrations in blood of the tested cows were within the lowest physiological limit (1.3 - $6.0 \mathrm{mmol} \cdot \mathrm{l}^{-1}$, Jovanović 1984). Contents of the total cholesterol in the blood of ketotic cows were determined to be significantly lower $(p<0.05)$ than the levels in the healthy groups of cows before and after calving. These results were in accordance with the results of other authors (Herdth 1983; Gerloff et al. 1986; Holtenius 1989; Sevinc et al. 2003), indicating that in cases of ketosis and fatty infiltration of liver cells in dairy cows, their ability to synthesise and transport cholesterol is decreased.

Dairy cows in early lactation are in a state of metabolic stress, in order to meet the needs of increased energy of the mammary gland and to adjust the neuro-endocrine system to the new metabolic needs of the body (Bauman and Currie 1980; Nikolić et al.1997). One of 
the endocrine factors are the thyroid hormones. In this study significantly lower $(p<0.05)$ $\mathrm{T}_{3}$ and $\mathrm{T}_{4}$ concentrations in blood were determined in the group of ketotic cows compared to the values of these hormones in the blood of healthy cows before and after calving. There is also a significant positive correlation $(\mathrm{r}=0.73 ; p<0.05)$ between the $\mathrm{T}_{3}$ and $\mathrm{T}_{4}$ levels in blood. Similar results have been obtained by other authors (Kapp et al. 1979; Gerloff et al. 1986; Nikolić et al. 1997; Stang et al. 1998b; Reist et al. 2002).

Romo et al. (1997) reported that in consequence of liver steatosis, FFA accumulate in the liver parenchyma, and it has been demonstrated that some fatty acids inhibit type-I liver 5'-deiodinase activity.

In accordance, Pezzy et al. (2003) assume that in dairy cows in early lactation, the state of hypothyroidism is present and it is the cause of the liver's decreased 5'-deiodinase activity or the secretion of thyroid hormones in milk.

The intensity of oxidation in mitochondria of cells is closely linked with the functional state of the thyroid gland, so it is justifiably considered that the conditions of negative energy balance and the increased lipid mobilisation from bodily fat reserves result in lipid infiltration of liver cells. The reason is the decreased capacity of mitochondria (with decrease the number following simultaneous size increase of mitochondria and mitochondrial damage) to oxidize fatty acids in the conditions of low concentrations of thyroid hormones in blood (Kapp et al. 1979; Johannsen et al. 1993; Nikolić et al. 1997; Stang et al. 1998b).

The results confirm these opinions, values of $T_{3}$ and $T_{4}$ in blood of ketotic cows were significantly lower $(p<0.05)$ than those of the healthy ones. Within all tested cows with ketosis, the fat infiltration of liver was determined, especially in cows with severe fatty liver $(>40 \%)$ the lowest values of the $\mathrm{T}_{3}\left(<1.00 \mathrm{nmol} \cdot \mathrm{l}^{-1}\right)$ and those of $\mathrm{T}_{4}\left(<15 \mathrm{nmol} \cdot \mathrm{l}^{-1}\right)$ were established (physiological range $\mathrm{T}_{3}$ : around $1.5 \mathrm{nmol}^{-1} \mathrm{l}^{-1} ; \mathrm{T}_{4}: 40-80 \mathrm{nmol} \cdot \mathrm{l}^{-1}$; Jovanović 1984). Negative correlation $(\mathrm{r}=-0.50 ; p<0.05)$ between the $\mathrm{T}_{3}$ and FFA concentrations in blood of ketotic cows is confirmed, as well.

Our investigations suggested that a hypothyroidal status was established in ketotic cows and that the blood concentrations of free fatty acids, triacylglycerols, total cholesterol and glucose served as major biochemical indicators in determining liver steatosis in the dairy cows in transitional period.

\section{Koncentrace hormonů štítné žlázy a lipidů v krvi, množství lipidů v játrech dojnic v období stání na sucho}

Cílem studie bylo určit korelaci koncentrace hormonů štítné žlázy, lipidů a glukózy v krvi, jakož i množství lipidů v játrech dojnic v období stání na sucho. Zvířata $(\mathrm{n}=40)$ byla rozdělena do 4 skupin: první skupina sestávala z vysoce březích krav $(\mathrm{n}=10)$, které byly 10-4 dny před otelením, druhá skupina sestávala z vysoce březích krav $(\mathrm{n}=10)$, které byly 4-1 den před otelením, třetí skupina sestávala z klinicky zdravých krav v puerpériu (těsně po porodu) $(\mathrm{n}=10)$, zatímco čtvrtá skupina sestávala z krav v puerpériu, které měly ketózu $(\mathrm{n}=10)$. Od všech krav byly odebrány vzorky jater a krve. Histopatologické vyšetření vzorků jater prokázalo statisticky významně vyšší množství lipidů u krav v ketóze ve srovnání se zdravými krávami vysoce březími a v puerpériu. Biochemické vyšetření séra prokázalo signifikantně vyšší hodnoty volných mastných kyselin $(p<0,01)$ u krav v ketóze, stejně jako signifikantně nižší koncentrace glukózy $(p<0,01)$, triacylglycerolů $(p<0,01)$, celkového cholesterolu $(p<0,05)$, trijodtyroninu $(p<0,05)$ a tyroxinu $(p<0,05)$ ve srovnání s hodnotami zdravých krav před a po otelení. V této studii byla u krav v ketóze zjištěna signifikantní pozitivní korelace mezi množstvím lipidů v játrech a koncentrací volných mastných kyselin v krvi $(\mathrm{r}=0,51 ; p<0,05)$, stejně jako negativní mezi množstvím lipidů v játrech a koncentrací glukózy $(\mathrm{r}=-0,69 ; p<0,05)$, triacylglycerolů $(\mathrm{r}=-0,55$; 
$p<0,05)$ a celkového cholesterolu $(\mathrm{r}=-0,55 ; p<0,05)$ v krvi. Výsledky studie naznačují, že krávy v ketóze trpí hypothyreózou. Koncentrace volných mastných kyselin, glukózy, triacylglycerolů a celkového cholesterolu v krvi slouží jako významný biochemický indikátor steatózy jater u dojnic v období stání na sucho.

\section{Acknowledgment}

We want to express our acknowledgment to Prof Dr Tibor Gaal from Faculty of Veterinary Medicine in Budapest for help with the liver biopsy of dairy cows used in this experiment.

\section{References}

BAUMAN E, CURRIE W 1980: Partitioning of nutrients during pregnancy and lactation. A review of mechanisms involving homeostasis and homeorhesis. J Dairy Sci 63: 1514-1518

BLUM JW, KUNZ P, LEUENBERGER H, GAUTSCHI K, KELLER N 1983: Thyroid hormones, blood plasma metabolites and haematological parameters in relationship to milk yield in dairy cows. Anim Prod 36: 93-104

CODORNIGA-VALINO C, GRUMMER RR, ARMENTANO LE, DONKIN SS, BERTICS SJ 1997: Effects of fatty acids and hormones on fatty acids metabolism and gluconeogenesis in bovine hepatocytes. J Dairy Sci 80: 646-656

DYK PB, EMERY RS, LEISMAN JL, BUCHOLTZ HF, VANDER HAAR MJ 1995: Prepartum non-esterified fatty acids in plasma are higher in cows developing periparturient health problem. J Dairy Sci 78 (Suppl. 1): 264 (Abstract)

GAAL T 1995: Fatty liver syndrome in milk cows. Vet Glasnik 47: 311-319 (In Serbian)

GERLOFF B, HERDT T, EMERY R 1986: Relationship of hepatic lipidosis to health and performance in dairy cattle. J Am Vet Med Assoc 188: 845-849

EINER RF, EMERY RS 1986: Inositol and hepatic lipidosis. II. Effect of inositol supplementation and time from parturition on serum insulin, thyroxine and triodothyronine and their relationship to serum and liver lipids in dairy cows. J Anim Sci 62: 1693-1702

GRUMMER RR 1993: Etiology of lipid related metabolic disorders in periparturient dairy cows. J Dairy Sci 76: 3882-3896

GRUMMER RR 1995: Impact of changes in organic nutrient metabolism on feeding the transition dairy cows. J Anim Sci 73: 2820-2833

HOJOVCOVA M, KACAFIREK A 1967: Liver biopsy in cattle. Acta Univ Agric Brno 36: 513-520

HERDT TH, LEISMAN JS, GERLOFF BJ, EMERY RS 1983: Reduction of serum triacylglycerol-rich lipoprotein concentrations in cows with hepatic lipidosis. Am J Vet Res 44: 293-296

HOLTENIUS P 1989: Plasma lipids in normal cows around partus and in cows with metabolic disorders with and without fatty liver. Acta Vet Scand 30: 441-445

JOHANNSEN U, MENGER S, STAUFENBIEL R, ROSSOW N 1993: Investigations on morphology and function of the liver of high-yielding cows two weeks post partum. Dtsch Tierarztl Wochenschr 100: 177-181 (In German)

JOVANOVIĆ M 1984: Physiology of domestic animals. Medicinska knjiga, Beograd - Zagreb, p. 34 and p. 438 (In Serbian)

KAPP P, PETHES GY, ZSIROS M, SCHUSTER Z 1979: Contribution to the development of the fatty liver syndrome in high producing dairy-cows. Magy Állatorv Lapja 34: 458-461

KÉGL T, GAAL T 1992: Ketonuric Index - A new practical indicator to evaluate energy balance of dairy cows. Magy Állatorv Lapja 47: 159-161

NIKOLIĆ JA, ŠAMANC H, BEGOVIĆ P, DAMJANOVIĆ Z, DJOKOVIĆ R, KOSTIĆ G, KRSMANOVIĆ J, RESANOVIĆ V 1997: Low peripheral serum thyroid hormone status independently affects the hormone profile of healthy and ketotic cows during the first week postpartum. Acta Vet Beograd 47: 3-13

NIXON DA, AKASHA MA, ANDERSON RR 1988: Free and total thyroid hormones in serum of Holstein cows. J Dairy Sci 71: 1152-1160

OVERTON TR, WALDRON MR 2004: Nutritional management of transition dairy cows: Strategies to optimize metabolic health. J Dairy Sci 87: E105-E119

PEZZY C, ACCORSI PA, VIGO D, GOVANI N, GAIANI R 2003: 5'-Deiodinase activity and circulating thyronines in lactating cows. J Dairy Sci 86: 152-158

REIST M, ERDIN D, VON EUW D, TSCHUEMPERLIN K, LEUNBERGER H, CHILLIARD H, HAMMON M, MOREL C, PHILOPONA C, ZBINDER Y, KUENZI N, BLUM JW 2002: Estimation of energy balance at the individual and herd level using blood and milk traits in high-yielding dairy cows. J Dairy Sci $\mathbf{8 5}$ : 3314-3327

REYNOLDS CK, AIKMAN PC, LUPOLI B, HUMPHEIRS DJ, BEEVER DA 2003: Splanchnic metabolism of dairy cows during the transition from late gestation through early lactation. J Dairy Sci 86: 1201-1217

ROMO GA, ELSASSER TH, KHAL S, ERDMAN RA, CASPER DP 1997: Dietary fatty acids modulate hormone responses in lactating cows: Mechanistic role for 5'-deiodinase activity in tissue. Domest Anim Endocrin 14: $409-420$ 
ROSENBERGER G 1979: Clinical examination of cattle. Verlag Paul Parey, Berlin and Hamburg, p. 135 and p. 277

SEVINC M, BASOGLU A, GUZELBEKTA H 2003: Lipid and lipoprotein levels in dairy cows with fatty liver. Turk J Vet Anim Sci 27: 295-299

STANG BD, BERTICS SJ, GRUMMER RR, ARMENTANO LE 1998 b: Relationship of triglyceride accumulation to insulin clearance and hormonal responsiveness in bovine hepatocytes. J Dairy Sci 81: 740-747

VÁZQUEZ-AÑÓN M, BERTICS S, LUCK M, GRUMMER RR 1994: Peripartium liver triglyceride and plasma metabolites in dairy cows. J Dairy Sci 77: 1521-1528

VEENHUIZEN JJ, DRACKLEY JK, RICHARD MJ, SANDERSON TP, MILLER LD, YOUNG JW 1991: Metabolic changes in blood and liver during development and early treatment of experimental fatty liver and ketosis in cows. J Dairy Sci 74: 4238-4253

YOUNG JW 1977: Gluconeogenesis in cattle: significance and methodology. J Dairy Sci 60: 1-15 